\title{
Bacterial and Fungal Loads in Raw Sea Foods, Fruits and Vegetables collected from Dhaka, Bangladesh and the Effect of Heat on its Growth
}

\author{
Farahnaaz Feroz ${ }^{1,2 *}$, Miho Mori², Yoshikazu Sakagami ${ }^{2}$ \\ ${ }^{I}$ Department of Microbiology, Stamford University Bangladesh, 51 Siddeswari Road, 1217 Dhaka, Bangladesh, ${ }^{2}$ Kindai University, Faculty of \\ Agriculture, 3327-204 Nakamachi, Nara City, Nara 631-8505, Japan.
}

\begin{abstract}
Foods, fruits and vegetables are essential foodstuffs which can also serve as a major source of bacterial and fungal transmission. Mishandling of fruits, vegetables and foods during storage, transport, inadequate preparation and unsanitary conditions during processing have led to the spread of foodborne diseases worldwide, especially in Bangladesh. A total of 51 samples of fruits $(n=16)$, vegetables $(n=16)$ and seafoods $(n=19)$ were studied for the determination of bacterial and fungal loads and assessment of heat effect on microbial growth. All categories of 51 samples showed initial bacterial counts ranging from $4 \times 10^{3}-7 \times 10^{6}$ cfu/g, and fungal counts ranging from $10^{3}-10^{6} \mathrm{cfu} / \mathrm{g}$. Fruits, vegetables and seafood samples showed bacterial counts ranging from $4 \times 10^{3}-4 \times 10^{5}, 5 \times 10^{4}-1 \times 10^{6}$, and $3 \times 10^{4}-7 \times 10^{6}$, and fungal counts ranging from $6 \times 10^{3}-1 \times 10^{5} / \mathrm{g}, 9 \times 10^{4}-7 \times 10^{5} / \mathrm{g}$, and $1 \times 10^{3} 1 \times 10^{6} / \mathrm{g}$, respectively. Just after microbiological analyses, all different categories of samples were heat treated at $60^{\circ} \mathrm{C}$ for three intervals viz 30 minutes, 1 hour and finally 2 hours. Heating at $60^{\circ} \mathrm{C}$ showed efficiency in reducing bacterial and fungal growth in the samples studied with log reductions not venturing below the $\mathbf{1 . 0 0}$ mark and various samples with log reductions more than 5.00.
\end{abstract}

Key Words: Bacteria, fungus, load, raw foods, heat treatment

\section{Introduction}

Food, fruits, vegetables and water are major source of bacterial and fungal transmission ${ }^{1}$. Raw fruits and some categories of raw vegetables contain various nutrients and possess many health benefits $^{2}$. The rise in its consumption can also be contributed to the different campaigns, such as the 5 a day program, run by different government institutions ${ }^{3}$. Vegetables play important roles to combat against cardiovascular and cancerous diseases 4. They also posses antioxidants which help in protecting cells from being attacked by free radicals, and provide other benefits including DNA repair, longevity and cell maintenance ${ }^{2}$.

World Health Organization (WHO) and Food and Agricultural Organization (FAO) reported a yearly increase of $4.5 \%$ in the consumption of fresh fruits and vegetables between 1994 and $2004^{2}$. Iran has been one of the many countries to undergo an increase in the consumption of fresh produces ${ }^{5}$. Various European countries have also observed the same increase in consumption 3 . Awareness of the nutritional benefits attributed as a causative factor in the rise of consumption of fresh produces ${ }^{2}$. Perhaps this has contributed to the recent rise in the number of cases of human infections associated with minimally processed vegetables and other raw foods ${ }^{2,6,7}$. Seafood plays a role in the spread of foodborne illnesses, as for example, sea fish originating from polluted water may contribute to illnesses, often involving biotoxins ${ }^{8}$.
Despite all the benefits, mishandling during storage, transport and inadequate preparation have led to the spread of food-borne diseases 4,5 . Different reports have expressed the presence of microorganisms, viruses and parasites on fresh food ${ }^{5,7}$. Several studies have identified the presence of Escherichia coli $\mathrm{O} 157: \mathrm{H} 7$, Salmonella Typhimurium and Salmonella newport in fresh leafy produces ${ }^{9}$. Even in Bangladesh, foodborne illnesses are caused largely due to unsanitary conditions during processing ${ }^{10}$. Pathogens such as Salmonella typhi, Campylobacter spp., $V$. cholerae, $V$. vulnificus and $V$. parahaemolyticus have been associated with contaminated seafoods ${ }^{8}$. Moreover, the recent advances in diagnostic methods and surveillance methods have positively identified fresh produces as the source of food- borne illnesses ${ }^{2}$. These may occur due to exposure to various other sources of contamination at farms or market, such as fertilizers and soil organisms ${ }^{5,10-12}$.

Disinfection is critical to eliminate the risk of infection, with traditional disinfection relying heavily of washing. Washing is effective in removing dirt, pesticide residue along with microorganisms, which cause quality loss ${ }^{13}$. Researchers have been attempting to find alternative methods of disinfection, such as pressure and heat treatments ${ }^{14}$. Heat treatments have been gaining momentum, as they do not rely on any chemicals, generally relying on hot water dips, vapor heat or hot air treatments. Current study attempted to identify the microbiological loads of raw foods, 
collected from Dhaka City, Bangladesh and to demonstrate the effect of heat on the microorganisms in fruits, vegetables and food, as to establish heat as an effective, low cost and easy to use method of disinfection.

\section{Materials and Methods}

\section{Sample collection}

Raw fruit $(n=16)$ and vegetable samples $(n=16)$ were collected from local street markets and superstores early in the morning. Raw seafood samples $(n=19)$ were collected from fish markets in a cool box. All samples were immediately transferred to the Microbiological Laboratory at Stamford University, Bangladesh, Siddeshwari, Dhaka. All categories of samples are listed in Table 1.

\section{Estimation of Bacterial and Fungal Loads}

Raw sample was aseptically cut into small pieces. Then 10 grams of the sample was homogenized for $1 \mathrm{~min}$ in sterilized $90 \mathrm{ml}$ of physiological saline using a stomacher (Model No. 061-21001; Atect Co. Ltd, Japan). From this homogenate, serial dilutions (upto $\left.10^{-4}\right)$ were prepared and surface plated $(0.1 \mathrm{ml}$, in duplicate) on Nutrient Agar (NA) and Sabaroud Dextrose Agar (SDA). NA plates were incubated at $37^{\circ} \mathrm{C}$ for 48 hours, while the SDA plates were incubated at $25^{\circ} \mathrm{C}$ for 5 days. After incubation, the bacterial counts and fungal counts per gram were calculated from NA plates and SDA plates, respectively. The results are listed in Table 2 .

Effects of heat on bacterial and fungal growth.

The remaining sample cuts of all samples just after microbiological test were transferred into the sterilizer at $60^{\circ} \mathrm{C}$ for 3 intervals viz 30 minutes, 1 hour and 2 hours. After treatment, total bacterial counts and total fungal counts/g were determined by the methods mentioned above. The results are listed in Tables 3 and 4.

\section{Results}

Estimation of Bacterial and Fungal Loads

Fifty-one raw food samples from 3 categories are listed in Table 1.

From Table 2, it was apparent that TVBC and TVFC were 4 X $10^{3}$ - 7 X $10^{6} \mathrm{CFU} / \mathrm{g}$ and 1 X $10^{3}-1$ X $10^{6} \mathrm{CFU} / \mathrm{g}$, respectively. Among three categories of samples studied, seafood and fruit samples contained the highest and the lowest TVBC and fungal counts, respectively.

\section{Effects of heat on bacterial growth}

Effect of heat on bacterial growth in fruit, vegetables and seafood samples are shown in Tables $3 \mathrm{a}$ and $\mathrm{b}$.

Table 1. List of raw food samples.

\begin{tabular}{|c|c|c|}
\hline Type of samples & Sample size & Sample \\
\hline Fruits & 16 & $\begin{array}{l}\text { Apple, Tangerine, Orange, Banana, Guava, Mango, } \\
\text { Pears, Green Apple, Grapes, Dragon Fruit, Papaya, } \\
\text { Sapodilla, Berry, Wax Apple, Wood Apple, Sugar Cane, }\end{array}$ \\
\hline Vegetables & 16 & $\begin{array}{l}\text { Okra, Eggplant, Carrot, Tomato, Potato, Cauliflower, } \\
\text { Lettuce, Onion, Spinach, Peas, Red Amaranth, Cabbage, } \\
\text { Coriander, Bitter Gourd, Radish, Bottle Gourd, }\end{array}$ \\
\hline Seafood & 19 & $\begin{array}{l}\text { Swamp Barb, Stinging Catfish, Tengra, Indian Mottle } \\
\text { Eel, Scribbled Gobi, Yellow Tail, Mozambique Tilapia, } \\
\text { Bata, Freshwater Garfish, Dwarf Gourami, Walking } \\
\text { Catfish, Olive Barb, Annandale Loach, Ganger River } \\
\text { Sprat, Square Head Catfish, Rohu, Pabo Catfish, Prawn, } \\
\text { Golden Mahseer }\end{array}$ \\
\hline
\end{tabular}

Table 2. Determination of viable bacterial and fungal counts in raw fruits, vegetables and food samples.

\begin{tabular}{llll}
\hline Sample type & Sample size & $\begin{array}{l}\text { Total viable bacterial } \\
\text { counts }(\mathrm{CFU} / \mathrm{g})\end{array}$ & $\begin{array}{l}\text { Total fungal } \\
\text { counts }(\mathrm{CFU} / \mathrm{g})\end{array}$ \\
\hline Friuts & 16 & $4 \times 10^{3}$ to $4 \times 10^{5}$ & $6 \times 10^{3}$ to $1 \times 10^{5}$ \\
Vegetables & 16 & $5 \times 10^{4}$ to $1 \times 10^{6}$ & $9 \times 10^{4}$ to $7 \times 10^{5}$ \\
Sea foods & 19 & $3 \times 10^{4}$ to $7 \times 10^{6}$ & $1 \times 10^{3}$ to $1 \times 10^{6}$ \\
\hline Total samples & 51 & $4 \times 10^{3}$ to $7 \times 10^{6}$ & $1 \times 10^{3}$ to $1 \times 10^{6}$ \\
\hline
\end{tabular}


Among the vegetables tested (Table $3 \mathrm{a} \& \mathrm{~b}$ ), 3 samples showed log reductions of 3.00 and higher (Bottle Gourd, Lettuce and Okra in ascending order), whereas one sample was below 1.00 (Egg plant; 0.67). 4 samples of the fruits demonstrated log reductions of more than 3.5 (Banana, Green Apple, Green Grapes and Dragon Fruit), whereas Berry showed the lowest $\log$ reduction of 0.76 . Sufficient $\log$ reductions were observed among the seafood, with most samples demonstrating a log reduction of 3.00 and higher. Low reductions were still visible with Pabo catfish and Golden Mahseer (0.70 and 1.48 respectively).

\section{Effects of Heat on Fungal loads}

As seen in Tables $4 \mathrm{a} \& \mathrm{~b}$, heat was efficient in reducing fungal growth with $\log$ reductions not venturing below the 1.00 mark and various samples of $\log$ reductions more than 5.00. 5 vegetables (Okra, Lettuce, Peas, Bitter Gourd, Bottle Gourd) had log reductions 5.00 and higher. On contrast fruits had slightly lower reductions mostly ranging from 4.00 (Grapes) to 4.36 (Berry). Similarly, the higher log reductions for sea foods ranged from 4.04 (Square head catfish) and 5.34 (Golden Mahseer). Among all the raw foods tested the most insignificant log reduction was observed in coriander with a value of 1.25 and spinach with a value of 1.33 .

Table 3a: Effects of heat on bacterial Growth in raw food samples (Log cfu/g).

\begin{tabular}{|c|c|c|c|c|c|}
\hline Sample Name & 0 Hours & $30 \mathrm{~min}$ & 1 hour & 2 hour & Log Reduction \\
\hline Okra & 6.40 & 4.36 & 3.08 & 2.81 & 3.59 \\
\hline Eggplant & 4.41 & 4.34 & 4.08 & 3.74 & 0.67 \\
\hline Carrot & 5.48 & 4.48 & 3.43 & 3.08 & 2.40 \\
\hline Tomato & 5.23 & 4.36 & 3.46 & 3.26 & 1.97 \\
\hline Potato & 4.46 & 4.30 & 3.36 & 2.28 & 2.18 \\
\hline Cauliflower & 4.29 & 4.39 & 3.18 & 2.60 & 1.69 \\
\hline Lettuce & 5.99 & 4.30 & 3.18 & 2.60 & 3.39 \\
\hline Onion & 4.38 & 4.36 & 4.32 & 3.11 & 1.27 \\
\hline Spinach & 4.26 & 4.32 & 4.00 & 3.18 & 1.08 \\
\hline Peas (Borboti) & 5.26 & 4.32 & 4.39 & 3.28 & 1.98 \\
\hline Red Amaranth & 5.46 & 5.32 & 4.32 & 3.04 & 2.42 \\
\hline Cabbage & 5.15 & 5.30 & 4.18 & 3.11 & 2.04 \\
\hline Coriander & 5.15 & 5.00 & 4.30 & 3.28 & 1.87 \\
\hline Bitter Gourd & 5.46 & 4.11 & 3.04 & 2.95 & 2.51 \\
\hline Raddish & 5.39 & 5.32 & 4.15 & 3.04 & 2.35 \\
\hline Bottle Gourd & 5.30 & 4.32 & 3.15 & 2.30 & 3.00 \\
\hline Apple & 4.26 & 5.18 & 4.30 & 3.04 & 1.22 \\
\hline Tangerine & 5.34 & 4.30 & 3.48 & 2.00 & 3.34 \\
\hline Orange & 5.00 & 4.49 & 3.40 & 2.00 & 3.00 \\
\hline Banana & 3.59 & 3.47 & 2.60 & 0.00 & 3.59 \\
\hline Guava & 4.15 & 4.36 & 3.47 & 2.00 & 2.15 \\
\hline Mango & 4.20 & 4.07 & 3.15 & 2.95 & 1.25 \\
\hline Pears & 4.29 & 4.30 & 3.34 & 2.70 & 1.59 \\
\hline Green Apple & 3.94 & 3.41 & 2.30 & 0.00 & 3.94 \\
\hline
\end{tabular}


Table 3b: Effects of heat on bacterial growth in raw food samples (Log cfu/g).

\begin{tabular}{|c|c|c|c|c|c|}
\hline Sample Name & 0 Hours & $30 \mathrm{~min}$ & 1 hour & 2 hours & Log Reduction \\
\hline Dragon fruit & 4.04 & 3.18 & 2.48 & 0.00 & 4.04 \\
\hline Papaya & 4.11 & 4.00 & 3.48 & 2.70 & 1.41 \\
\hline Berry & 3.90 & 5.48 & 4.57 & 3.14 & 0.76 \\
\hline Wax apple & 4.40 & 4.32 & 3.08 & 2.00 & 2.40 \\
\hline Wood Apple & 5.56 & 4.40 & 4.00 & 3.32 & 2.24 \\
\hline Swamp Barb (Puti) & 6.32 & 6.30 & 5.08 & 3.20 & 3.12 \\
\hline Stinging Catfish (Shingi) & 5.48 & 4.30 & 3.14 & 2.28 & 3.20 \\
\hline Tengra & 5.48 & 5.30 & 4.14 & 3.11 & 2.37 \\
\hline Indian Mottle eel (Bair) & 5.48 & 5.30 & 4.18 & 3.30 & 2.18 \\
\hline Scribbled Gobi (Bele) & 6.48 & 5.40 & 4.46 & 3.11 & 3.37 \\
\hline Yellow Tail (kechki) & 5.48 & 4.57 & 3.28 & 2.30 & 3.18 \\
\hline Dwarf Gourami (Khoilsha) & 5.32 & 5.28 & 4.28 & 3.38 & 1.94 \\
\hline Walking Catfish (Koi) & 6.51 & 5.26 & 4.18 & 3.30 & 3.21 \\
\hline Olive barb (Sharpoti) & 5.49 & 5.39 & 4.39 & 3.40 & 2.09 \\
\hline Annandale Loach (Gutum) & 5.41 & 4.15 & 3.56 & 2.30 & 3.11 \\
\hline Ganjer river sprat (Kechi) & 5.43 & 5.45 & 4.95 & 3.26 & 2.17 \\
\hline Squarehead Catfish (Cheka) & 4.48 & 4.55 & 3.23 & 2.36 & 2.12 \\
\hline Rohu & 5.48 & 4.15 & 3.34 & 2.48 & 3.00 \\
\hline Pabo catfish (Pabda) & 4.48 & 4.32 & 4.04 & 3.78 & 0.70 \\
\hline Prawn & 5.36 & 5.54 & 4.32 & 3.04 & 2.32 \\
\hline Golden Mahseer (Mohosho) & 4.38 & 4.20 & 3.15 & 2.90 & 1.48 \\
\hline
\end{tabular}

Table 4a: Effects of heat on fungal growth in raw food samples (Log cfu/g).

\begin{tabular}{|c|c|c|c|c|c|}
\hline Sample Name & 0 hour & $30 \mathrm{~min}$ & 1 hours & 2 hours & Log reduction \\
\hline Eggplant & 4.41 & 3.74 & 2.85 & 0.00 & 4.41 \\
\hline Tomato & 4.45 & 3.88 & 2.48 & 0.00 & 4.45 \\
\hline Potato & 4.20 & 4.04 & 3.36 & 2.28 & 1.92 \\
\hline Cauliflower & 4.26 & 4.04 & 3.85 & 2.00 & 2.26 \\
\hline Onion & 4.38 & 4.36 & 3.85 & 2.00 & 2.38 \\
\hline Spinach & 4.23 & 4.34 & 3.08 & 2.90 & 1.33 \\
\hline Peas (Borboti) & 5.46 & 3.93 & 2.95 & 0.00 & 5.46 \\
\hline Red Amaranth & 5.38 & 4.32 & 3.18 & 2.95 & 2.43 \\
\hline Cabbage & 4.08 & 3.98 & 3.00 & 2.00 & 2.08 \\
\hline Coriander & 4.15 & 4.18 & 3.32 & 2.90 & 1.25 \\
\hline Apple & 4.18 & 3.32 & 2.48 & 0.00 & 4.18 \\
\hline Tangerine & 4.08 & 3.26 & 2.30 & 0.00 & 4.08 \\
\hline Orange & 4.11 & 3.40 & 2.00 & 0.00 & 4.11 \\
\hline Banana & 3.97 & 3.40 & 2.00 & 0.00 & 3.97 \\
\hline Guava & 3.57 & 3.95 & 2.85 & 0.00 & 3.57 \\
\hline Mango & 4.15 & 3.18 & 0.00 & 0.00 & 4.15 \\
\hline Pears & 4.15 & 3.48 & 2.30 & 0.00 & 3.46 \\
\hline Green Apple & 3.46 & 3.26 & 2.90 & 0.00 & 3.15 \\
\hline Green Grape & 3.15 & 3.60 & 2.95 & 0.00 & 3.86 \\
\hline
\end{tabular}


Bacterial and Fungal Loads in Raw Sea Foods, Fruits and Vegetables collected

Table 4b: Effects of heat on fungal growth in raw food samples (Log cfu/g).

\begin{tabular}{|c|c|c|c|c|c|}
\hline Sample Name & 0 hour & $30 \mathrm{~min}$ & 1 hour & 2 hours & Log reduction \\
\hline Dragon fruit & 3.86 & 3.04 & 2.00 & 0.00 & 4.00 \\
\hline Papaya & 4.00 & 3.26 & 3.70 & 0.00 & 4.18 \\
\hline Sapodilla & 4.18 & 4.18 & 2.30 & 0.00 & 3.81 \\
\hline Berry & 3.81 & 3.54 & 2.23 & 0.00 & 4.36 \\
\hline Wax apple & 4.36 & 3.32 & 0.00 & 0.00 & 4.28 \\
\hline Wood Apple & 4.28 & 2.00 & 3.30 & 2.60 & 1.72 \\
\hline Sugar cane & 4.32 & 4.36 & 3.70 & 2.30 & 1.74 \\
\hline Swamp Barb (Puti) & 4.04 & 4.08 & 2.40 & 0.00 & 4.48 \\
\hline Stinging Catfish (Shingi) & 4.48 & 3.60 & 3.38 & 2.85 & 3.61 \\
\hline Tengra & 6.46 & 4.40 & 3.30 & 2.90 & 1.56 \\
\hline Indian Mottle eel (Bair) & 4.46 & 4.26 & 4.43 & 2.85 & 2.64 \\
\hline Scribbled Gobi (Bele) & 5.49 & 5.36 & 3.30 & 2.11 & 2.12 \\
\hline Yellow Tail (kechki) & 4.23 & 4.46 & 4.26 & 3.45 & 2.00 \\
\hline Mozambique Telapia & 5.45 & 5.58 & 3.40 & 2.08 & 2.38 \\
\hline Bata & 4.46 & 4.69 & 3.08 & 2.15 & 2.33 \\
\hline Fresh Water garfish (Kaika) & 4.48 & 4.28 & 3.18 & 2.26 & 2.72 \\
\hline DwarfGourami (Khoilsha) & 4.98 & 4.11 & 3.78 & 2.30 & 1.81 \\
\hline Walking Catfish (Koi) & 4.11 & 4.30 & 3.32 & 2.60 & 1.66 \\
\hline Olive barb (Sharpoti) & 4.26 & 4.32 & 2.30 & 0.00 & 3.99 \\
\hline Annandale Loach (Gutum) & 3.99 & 3.40 & 3.26 & 2.18 & 2.00 \\
\hline Ganjer river spral (Kechi) & 4.18 & 4.28 & 3.18 & 2.00 & 2.08 \\
\hline Squarehead Catfish (Cheka) & 4.08 & 4.36 & 2.00 & 0.00 & 4.04 \\
\hline Rohu & 4.04 & 3.53 & 3.20 & 2.48 & 1.80 \\
\hline Pabo catfish (Pabda) & 4.28 & 4.28 & 2.95 & 0.00 & 4.32 \\
\hline Prawn & 4.32 & 3.18 & 3.91 & 2.00 & 2.30 \\
\hline Golden Mahseen (Mohosho) & 4.30 & 4.23 & 2.78 & 0.00 & 5.34 \\
\hline
\end{tabular}

\section{Discussion}

Current study attempted to identify the bacterial and fungal loads present in raw foods, collected from the supermarkets and open markets of Dhaka, Bangladesh. The study also attempted to identify the effects of heat on the growth of microbes and fungus. The study assesed the use of dry heat to decontaminate raw foods. The widespread knowledge of the nutritional benefits of fruits and vegetables, such as antioxidants property, and roles in DNA repair and longevity, has led to a rise in its consumption ${ }^{2}$. As a result, an increase in the incidence of foodborne illness has been observed, particularly among elderly and immunocompromised people.

The alarming increase of food borne illnesses in Dhaka, has led to a need for the development of safe, easy and cheap methods of decontamination. Previous studies have demonstrated high microbial and fungal counts in raw foods of Dhaka, Bangladesh and all around the world ${ }^{4,7,9}$. Coupled with the minimal access to clean water, this situation is establishing a negative effect on the health of the population.

Raw foods exhibited large microbial and fungal counts, painting an alarming scenario in the Bangladeshi food sector. $15 \%$ of the samples had exceeded the limit of microbial growth, which was unsuitable for human consumption; whereas, $45 \%$ of the foods were marginal. Open markets such as Ryer bazar market and the fish markets are typical types of market, catering only to a minority of the upper class family; it serves as the major source of produce, meats and fish for the majority of Bangladeshi citizens, particularly due to the ease of availability and lower prices of products. Current study also determined the air quality of the locations, to asses the relative effect of environmental pollutants on the foods. Elevated microbial and fungal counts were found in the environment, presenting air quality as a major contributing factor to the contamination of foods in open markets.

Studies in Ghana ${ }^{15}$ found similar microbial counts of fruits and vegetables ranging from $9.3 \times 10^{5}$ to 1.5 to $10^{11}$. Abadias et al. $(2008)^{3}$ in Spain also observed microbial counts that ranged around $10^{7}$ to $10^{8}$. Alternatively, their fungal counts varied from the current, expressing counts to be on a higher scale. In coherence with the current study, higher counts were observed in leafy vegetables with fruits generally expressing lower microbial and fungal counts. This can be a result of the acidic nature of the fruits combined with the temperature generally used for storing fruits in Bangladesh, usually refrigerated, aided by the peel, if present ${ }^{3}$. Studies by Jeddi et al. $(2014)^{5}$ have also found microbial counts to range between $10^{6}$ and $10^{7}$. Similar results were 
presented by Nipa et al. $(2011)^{16}$ for fruits and vegetables tested in Bangladesh. Additionally, studies by Rahman and Noor (2012) $)^{10}$ have also revealed increased bacterial and fungal loads among common salad vegetables, which are consumed raw. Therefore, the increased presence of pathogens will impact the incidences of foodborne illnesses.

The increase in foodborne disease, linked with raw foods, continues to be alarming, particularly produce, which are consumed raw ${ }^{8}$. As the source of these diseases may vary, proper precautions employed in order to reduce the burden. Heat is an established method used often in households and commercial settings but some studies have revealed nutritional and functional changes in food properties ${ }^{17}$. Heat treatment are applied to foods such as milk to increase shelf life and to reduce the presence of microorganism, but its full application in rendering foods free of organisms, is still in question ${ }^{18}$. Additionally, the previous studies have also reported a decrease in soil biota in relation to the effect of heat on the ecology of forests ${ }^{19}$. The knowledge on the effects of simple heat treatment on the samples will positively have impact the health and safety of the consumers. Heat was effective in reducing the microbial and fungal load in food samples studied, with $\log$ reduction of 2.00 and higher.

As foodborne illnesses continue to rise, studies on effective methods of decontaminating foods need to continue, in order to maintain the health of the community. Methods currently being used include gamma irradiation and fumigation ${ }^{20}$ and research on the application of low- pressure plasma sterilization in agriculture gained momentum ${ }^{21}$, but trust on the use of radiation is still in question. The use of heat on foods would ensure the quality of the foods without compromising nutritional benefits or affecting the profit margins of the food production and/or agricultural companies. Its application will greatly enhance the quality of the foods, particularly as it is a non-chemical method of disinfection.

\section{References}

1. Yoon JY and Kim B. 2012. Lab-On-Chip Pathogen Sensors for food Safety. Sensors 12: 10713-10741.

2. Caradamone C, Aleo A, Mammina C, Oliveri G, and Di Noto AM. 2015. Assesment of the microbiological quality of fresh produce on sale in Sicily, Italy: preliminary results. J. Biol. Res. Thessaloniki. 22(3): 1 .

3. Abadias M, Usall J, Anguera M, Solsona C, and Viñas I. 2008. Microbiological quality of fresh, minimally- processes fruit and vegetables and sprouts from retail establishments. Int. J. Food Microbiol. 123: 121-129.

4. Akter R, Tanu NI, and Uddin A. (2013) Isolation and quatification of bacterial isolates from citrus fruits and determination of their antibacterial activity against selected pathogens. Stamford J. Microbiol. 3(1): 30-33.
5. Jeddi MZ, Yunesian M, Gorji ME, Noori N, Pourmad MR, and Khaniki GRJ. 2014. Microbial Evalutaion of Fresh, Minimally- processed Vegetables and Bagged Sprouts from Chain Supermarkets. J. Health Popul. Nutr. 32(3): 391-399.

6. Buck JW, Walcott R, and Beuchat LR. 2003. Recent Trends in Microbiological Safety of Fruits and Vegetables. Online. Plant Management Network. Progress doi:10.1094/PHP-2003-0121-01$\mathrm{RV}$

7. Tsado EK, Adesina OA, and Oyeleke SB. 2013. A survey on the Bacterial Load of Selected Fruits and Leafy Vegetables in Minna Metropolis of Niger State, Nigeria. J. Animal. Prod. Adv. 3(1): 6-11.

8. Rose JB, Epstein PR, Lipp EK, Sherman BH, Bernard SM, and Patz JA. 2001. Env. Health Perspect. 129(2): 211-220.

9. Heaton JC and Jones K. 2008. Microbial contamination of fruit and vegetables and the behaviour of enteropathogens in the phyllosphere: a review. J. Appl. Microbiol. 104: 113-126.

10. Rahman F and Noor R. 2012. Prevalence of pathogenic bacteria in common salad vegetables of Dhaka. Int J Food Microbiol Metropolis. Bangladesh J. Bot. 42(1): 159-162.

11. Alam MS, Feroz F, Rahman H, Das KK and Noor R. 2015. Microbiological contamination sources of freshly cultivated vegetables. Nutr. and Food Sci. 44(4): 646-658.

12. Rahman H, Feroz F, Alam MS, Das KK, and Noor R. 2016. Demonstration of the source of microbial contamination of freshly cultivated cabbage, cauliflower, potato and squash collected from rural farms of Bangladesh. Int. Food Res. J. 23(3): 1289-1295.

13. Gil MI, Selma MV, López- Gálvez F, and Allende A. 2009. Fresh cut product sanitation and wash water disinfection: Problems and solutions. Int. J. Food Microbiol. 134: 37-45.

14. Vicente A and Castro I. 2007. Novel thermal processing technologies. In Advances in thermal and non-thermal food preservation. (Tewari G \& Juneja V eds.), Blackwell Publishing, Oxford, UK

15. Amoah P, Drechsel P, Abaido RC, and Ntow WJ. 2006. Pesticide and Pathogen Contamination of Vegetables in Ghana's Urban Markets. Arch. Env. Contam. and Toxicol. 50: 1-6.

16. Nipa MN, Mazumdar RM, Hasan MM, Fakruddin M, Islam S, Bhuiyan HR, and Iqbal A. 2011. Prevelance of Multi drug resistant bacteria on raw salad vegetables sold in major markets of Chittagong City, Bangladesh. Middle- East J. Sci. Res. 10(1): 70-77.

17. Cruz- Romero M, Kelly AL, Kerry JP. 2007. Effects of high pressure and heat treatments on physical and biochemical characteristics of oysters. Inno. Food Sci. and Emerg. Technol. 8: 30-38.

18. Raikos V. 2010. Effect of heat treatment on milk protein functionality at emulsion interfaces. A Rev. Food Hydrocoll. 24: 259-265.

19. Banning NC and Murphy DV. 2008. Effect of heat- induced disturbance on microbial biomass and activity on forest soil and the relationship between disturbance effects and microbial community structure. Appl. Soil Ecol. 40: 109-119.

20. Juri ML, Ito H, Watanabe H, and Tamura N. 1986. Distribution of Microorganisms in Spices and Their Decontamination by Gammairradiation. Agri. and Biol. Chem. 50(2): 347-355.

21. Nishioka T, Takai Y, Kaeardanu M, Okada K, Tanimoto H, Misawa T, and Kusakari S. 2014. Seed Disinfection Effect of Atmospheric Pressure Plasma and Low Pressure Plasma on Rhizoctonia solani. Biocont. Sci. 19(2): 99-102. 